\title{
Real Time PCR HBV-DNA Analysis in HBsAg Positive Patients
}

\author{
Rahman $\mathrm{W}^{1}$, Hossain $\mathrm{MR}^{2}$, Khan $\mathrm{AA}^{3}$, Saha $\mathrm{D}^{4}$, Alam $\mathrm{SMM}^{5}$, Yasmin $\mathrm{F}^{6}$
}

\begin{abstract}
Introduction: The hepatitis B virus is a global public health concern and leading cause of chronic liver disease in Bangladesh. For the diagnosis and monitoring of treatment of Hepatitis $B$ virus infection, HBV-DNA detection and quantification is now extensively used worldwide.
\end{abstract}

Objectives: The objective of this study was to detect HBV-DNA by real time PCR method in HBsAg positive patients, to compare the results of HBVDNA detection with $\mathrm{HBeAg}$ and $\mathrm{Anti}-\mathrm{HBe}$ and to monitor the response after antiviral therapy in chronic hepatitis $B$ patients and also to observe the intensity of hepatitis $B$ infection in relation to age and sex.

Methods: This was a cross sectional type of study conducted in Armed Forces Institute of Pathology (AFIP), Dhaka Cantonment. In this study, 56 sera of HBsAg positive patients were selected who all were subjected to do HBV-DNA (real time PCR) analysis during the period of 29 July to 30 October, 2013.

Results: Out of $56 \mathrm{HBsAg}$ positive patients, HBV-DNA was detected in 34 patients. Among these, $8(23.5 \%)$ patients were HBeAg positive, 16 $(47 \%)$ patients were anti-HBe positive and 10 $(29.5 \%)$ were negative for both $\mathrm{HBeAg}$ and anti-HBe. Age limit of patients was up to 60 years. HBV-DNA positive patients showed male predominance; 26 $(76.5 \%)$ patients were male and $8(23.5 \%)$ patients were female. Mean age of the patients was $35 \pm 14$ years. Among $56 \mathrm{HBsAg}$ positive patients, fifteen were receiving antiviral therapy. Out of them, HBV-DNA was decreased among 4 patients and could not be detected among 11 patients.
Conclusion: Real time PCR method of detection of HBV-DNA is very important in patients who are $\mathrm{HBeAg}$ negative and this method is also applied to monitor treatment response to antivirals and to detect occult HBV infections immune control phase and also to detect reactivation of HBV cases.

Key-words: HBV-DNA, real time PCR (rt-PCR), $\mathrm{HBeAg}$, anti-HBe.

\section{Introduction}

According to World Health Organization estimates, more than 2000 million people have been infected with HBV worldwide and about 350 million have persistent infection. HBV may be the cause of up to $80 \%$ of all cases of hepatocellular carcinoma worldwide, second only to tobacco among known human carcinogens. Approximately, 1 million people around the world die each year from hepatocellular carcinoma or liver failure. Control of HBV infection is therefore, an important goal for public health in areas of endemicity ${ }^{1-5}$. Hepatitis $B$ virus is a double stranded DNA virus of the Hepadnaviridae family of approximately 3,200 base pairs $^{6-8}$. During the viral replication cycle, supercoiled covalently closed circular viral DNA (cccDNA) is generated and this DNA persists in host cells as a viral minichromosome. This cccDNA can be a source of renewed virus production once the immune response to the acute infection is over and thus constitutes a reservoir of infectious viral particles, thereby leading to the development of chronic hepatitis in certain individuals ${ }^{9,10}$. HBV-DNA can be detected approximately 21 days before HBsAg typically appears in the serum ${ }^{11}$. During the window period, when HBsAg

1. Maj Wasila Rahman, MBBS, MCPS (Clinical Pathology), DCP, Instructor of Pathology, AFMC, Dhaka; 2. Maj Gen Muhammad Rabiul Hossain, MBBS, MCPS, FCPS (Internal Medicine), Consultant Physician General, Bangladesh Armed Forces, Dhaka; 3. Col Arif Ahmed Khan, MBBS, MCPS, FCPS (Microbiology), Classified Spl in Microbiology, AFIP, Dhaka; 4. Maj Gen Debashish Saha, MBBS, FCPS (Chemical Pathology), MMED, Comdt, AFIP, Dhaka; 5. Brig Gen S M Mahbubul Alam, MBBS, MCPS, FCPS (Histopathology), Dy Comdt, AFIP, Dhaka; 6. Lt Col Farhana Yasmin, MBBS, DCP, FCPS (Microbiology), Classified Spl in Microbiology, AFIP, Dhaka. 
has disappeared and anti-HBs is not yet detectable, HBV-DNA detection can be useful to detect HBV infectious status ${ }^{8}$. Moreover, it is now evident that a group of HBV infected persons may not express $\mathrm{HBsAg}$ in the sera due to various factors. Several cases of post-transfusion hepatitis have also occurred after transfusion of HBsAg-negative blood. However, nothing is known about the entity of occult HBV infection or HBsAg-negative HBV-infected subjects in Bangladesh ${ }^{12}$.

Hepatitis B is a complex disease which needs serological, biochemical, molecular \& histological evaluation for diagnosis ${ }^{13}$. Recently, the level of HBV-DNA in serum or plasma has been shown to correlate with biochemical and histological measures of disease, and probably reflects more accurately the replicative activity of HBV. Therefore, the measurement of HBV-DNA in serum has become an important tool to identify individuals with high viral replication and to monitor patients on therapy ${ }^{3}$. Various quantitative assays are now used extensively to quantify the level of HBV-DNA load in serum samples. Among them real time PCR is highly sensitive. HBV-DNA persists throughout both acute and chronic disease \& can be more accuratly detected than $\mathrm{HBeAg}$. It is detectable prior to biochemical evidence of hepatitis ${ }^{13}$.

\section{Materials and methods}

This is a retrospective, cross sectional type of study which was conducted in AFIP, Dhaka Cantonment. The study was carried out from 29 July, 2013 to 30 October, 2013. Study populations were HBsAg positive patients of both sex and age limit was up to 60 years. A total of $56 \mathrm{HBsAg}$ positive patients were identified from $\mathrm{CMH}$, Dhaka cantonment, Dhaka. Relevant history was taken from the patients. With the written consent of the patients, firstly, HBV-DNA was detected and quantified by rt-PCR in the molecular biology laboratory, AFIP and secondly, serum $\mathrm{HBeAg}$ and anti-HBe were detected by ELISA in the Immunology Department, AFIP, Dhaka Cantonment.

Detection and quantitation of HBV-DNA by rt PCR: The detection was done by the fluorescent labelling of oligonucleotide probes that bind specifically to the PCR amplicone. Detection of the fluorescence intensity during the course of rt-PCR enables verifi- cation as well as quantitation of the product. For HBV-DNA the artus HBV RG PCR kit (QIAGEN, Germany) covers a linear range from $1.1 \mathrm{IU} / \mathrm{ml}$ to at least $4 \times 10^{9} \mathrm{lU} / \mathrm{ml}$.

DNA extraction: DNA was extracted from $200 \mu$ of plasma with DNA extraction kit, dissolved in buffer and stored at $-20^{\circ} \mathrm{C}$ till used for PCR.

Real time PCR: The HBV Rotor Gene PCR kit was ready to use for real time PCR. The HBV RG Master contained all the reagents and enzymes for the specific amplification of a 134 base pair sequence of the HBV genome and for the direct detection of the specific amplicon in fluorescence channel Cycling Green of the Rotor-Gene Q. In addition, the artus HBV RG PCR kit contained a second heterogonous amplification system to identify possible PCR inhibition. This was detected as an internal control in fluorescence Finally the amplification was performed in a $50 \mu \mathrm{l}$ reaction mixture containing $30 \mu \mathrm{l}$ mixture of HBV RG Master mix (Buffer, dNTP, Primer, Probe and enzymes) and $20 \mu$ l of eluted sample DNA to each reaction. Correspondingly, $20 \mu \mathrm{l}$ of 5 quantitation standards were used as positive controls and $20 \mu \mathrm{l}$ of water as a negative control. The rt-PCR cycling parameters consisted of denaturation at $95^{\circ} \mathrm{C}$ for 10 minutes followed by 45 cycles consisting of $95^{\circ} \mathrm{C}$ for $15 \mathrm{sec}, 5^{\circ} \mathrm{C}$ for 30 sec and $72^{\circ} \mathrm{C}$ for 15 seconds.

The problem of contamination was avoided by using pre-sterilized filtered micro tips and the reaction was run in a closed system. The amplification detection was carried out in a Rotor Gene $Q$ Sequence detector. The rt-PCR uses target amplification techniques in which quantitation takes place during the exponential phase of amplification reaction.

\section{Results}

A total of $56 \mathrm{HBsAg}$ positive patients were selected for the present study. Among them, HBV-DNA was detected among $34(60.7 \%)$ patients. Twenty two $(39.3 \%)$ patients were negative for the test (Table-I).

Table-I: Detection of HBV-DNA by rt PCR among HBsAg positive patients $(n=56)$.

\begin{tabular}{|c|c|c|c|}
\hline $\begin{array}{c}\text { Total } \\
\text { patients }\end{array}$ & $\begin{array}{c}\text { HBs Ag } \\
\text { positive }\end{array}$ & $\begin{array}{c}\text { HBV-DNA } \\
\text { Detected }\end{array}$ & $\begin{array}{c}\text { HBV-DNA Not } \\
\text { detected }\end{array}$ \\
\hline 56 & $56(100 \%)$ & $34(60.7 \%)$ & $22(39.3 \%)$ \\
\hline
\end{tabular}


Among 34 HBV-DNA positive patients, 8 (23.5\%) patients were $\mathrm{HBeAg}$ positive, $16(47 \%)$ patients were anti-HBe positive and $10(29.5 \%)$ were negative by both the tests. On the other hand, among 22 patients who were negative for HBV-DNA, none were $\mathrm{HBeAg}$ positive, 10 (45.5\%) patients were anti-HBe positive and 12 (54.5\%) patients were negative for both the tests $(\mathrm{HBeAg}$ and anti-HBe) (Table-II).

Table-II: Detection of HBV-DNA by rt-PCR and detection of $\mathrm{HBeAg}$, anti-HBe by ELISA in $\mathrm{HBsAg}$ positive patients $(n=56)$.

\begin{tabular}{|c|c|c|c|}
\hline $\begin{array}{l}\text { Detection } \\
\text { of HBV- } \\
\text { DNA }\end{array}$ & $\begin{array}{l}\text { HBeAg } \\
\text { positive }\end{array}$ & $\begin{array}{l}\text { Anti-HBe } \\
\text { positive }\end{array}$ & $\begin{array}{l}\text { Both HBeAg } \\
\text { \& anti-HBe } \\
\text { negative }\end{array}$ \\
\hline $\begin{array}{c}\text { Detected } \\
(34)\end{array}$ & $8(23.5 \%)$ & $16(47 \%)$ & $10(29.5 \%)$ \\
\hline $\begin{array}{c}\text { Not } \\
\text { Detected } \\
(22)\end{array}$ & $0(0 \%)$ & $10(45.5 \%)$ & $12(54.5 \%)$ \\
\hline Total & $8(14 \%)$ & $26(46.4 \%)$ & $22(39.2 \%)$ \\
\hline
\end{tabular}

Among 34 HBV-DNA positive patients 26 patients $(76.4 \%)$ were male and 8 patients $(23.5 \%)$ were female (Table-III). Mean age of these 34 patients was $35 \pm 14$ years.

Table-III: Sex distribution of HBV-DNA positive patients $(n=34)$.

\begin{tabular}{|l|c|c|}
\hline Sex & Total & Percentage \\
\hline Male & 26 & $76.5 \%$ \\
\hline Female & 8 & $23.5 \%$ \\
\hline
\end{tabular}

Among $56 \mathrm{HBsAg}$ positive patients, 15 patients were receiving anti-viral therapy. Out of them, 4 patients showed decreased viral load and HBV-DNA could not be detected in 11 patients (comparative study was done by taking the previous record of HBV-DNA load of the same patients from AFIP) (Table-IV).

Table-IV: Treatment response among the patients receiving anti-viral therapy $(n=15)$.

\begin{tabular}{|c|c|c|}
\hline $\begin{array}{c}\text { Treatment } \\
\text { receiving }\end{array}$ & \multicolumn{2}{|c|}{ HBV-DNA load after treatment } \\
\hline 15 & $\begin{array}{c}\text { Decreased } \\
\text { in 4 } \\
\text { patients }\end{array}$ & $\begin{array}{c}\text { Not detected } \\
\text { in } 11 \\
\text { patients }\end{array}$ \\
\hline Percentage & $26.6 \%$ & $73.4 \%$ \\
\hline
\end{tabular}

\section{Discussion}

The detection of viral DNA in serum is strong evidence that infectious virions are present ${ }^{8}$. HBV DNA levels are detectable by 30 days following infection, generally reach a peak at the time of acute hepatitis, and gradually decrease and disappear when the infection resolves spontaneously ${ }^{11}$.

In this study, among $56 \mathrm{HBsAg}$ positive patients, rt PCR detected HBV-DNA in $34(60.7 \%)$ patients and $22(39.3 \%)$ were negative for HBV-DNA. This finding correlates with a study by Ali Koyncver which was done among HBsAg positive patients and detected HBV-DNA in the serum of $58.3 \%$ patients and $41.7 \%$ patients were negative for HBV-DNA ${ }^{14}$.

Among 34 (60.7\%) HBV-DNA positive patients, 8 $(23.5 \%)$ were $\mathrm{HBeAg}$ positive which indicates that the patients may be in immune tolerance phase and $16(47 \%)$ patients were anti-HBe positive which indicates that the patients may be in immune clearance phase. These findings correlate with the studies by Danta et al and yun-fan et $\mathrm{al}^{13,15}$. Again, among these 34 HBV-DNA positive patients, $26(76.5 \%)$ patients were negative for $\mathrm{HBeAg}$. This correlates with the study by Maimuna E Mendy which showed that HBV-DNA was detected in $77.0 \%$ of $\mathrm{HBeAg}$ negative patients and all $\mathrm{HBeAg}$ positive patients ${ }^{16}$.

On the other hand, among $22(39.3 \%)$ HBV-DNA negative patients, none were $\mathrm{HBeAg}$ positive and 10 $(45.5 \%)$ patients were anti-HBe positive which indicates that the patients may be of silent infection which correlates with the study of MR Md et $\mathrm{al}^{17}$. Twelve (54.5\%) patients were negative by both the tests $(\mathrm{HBeAg}$ and anti-HBe) which indicates that the patients may be of precore mutant variety or carriers which correlate with the study of Yun-Fan et al ${ }^{15}$.

In this study, among the $56 \mathrm{HBsAg}$ positive patients, $\mathrm{HBeAg}$ was positive in $8(14.28 \%)$ patients which also coincides with the study by Chopra GS et al which showed that $26 \%$ patients were positive for $\mathrm{HBeAg}$ among HBsAg positive patients ${ }^{3}$.

The present data indicates that the $\mathrm{HBeAg}$ and anti-HBe status do not necessarily reflect the HBV-DNA level in the serum. So, the assay may be useful for patients who are HBeAg negative but carry 
the HBV virion ${ }^{18}$, as the precore point mutant HBVs cause $\mathrm{HBeAg}$ negative phenotype irrespective of their status of replication, ${ }^{3,19}$. Moreover, by Polymerase- Chain-Reaction (PCR) method, we know that $70 \%$ to $85 \%$ of people with anti-HBe antibodies have detectable viral DNA in the circulation to have some level of ongoing viremia ${ }^{20}$.

Among 34 HBV-DNA positive patients, 26 (76.4\%) were male and $8(23.5 \%)$ were female, thus depicting male predominance. Mean age of these 34 patients was $35 \pm 14$ years. These findings correlate with the study by Azita Ganji et al which also showed male predominance $(72.0 \%)$ and mean age of these subjects was $39 \pm 11$ years ${ }^{21}$. The detection and quantitation of HBV-DNA play an important role in diagnosis as well as monitoring HBV infection to assess therapeutic response to antiviral in chronic Hepatitis B patients ${ }^{22}$. Asymptomatic HBsAg positive carriers should not be considered as having inactive disease. They should be followed up every 3 to 6 months to know the activity of the disease and development of complications. Majority of these carriers suffer from chronic hepatitis rather than acute hepatitis probably contracting the disease in perinatal period or early childhood ${ }^{17}$.

HBV-DNA persists throughout the natural history of chronic hepatitis $B$, even in patients with serologic evidence of viral clearance. Ttreatment does not generally allow complete eradication of HBV from the organism. Continuous long-term therapy is required to maintain effective viral suppression and symptom control ${ }^{23}$. In the present study, among the 15 treatment receiving patients, viral load was decreased in $4(26.6 \%)$ patients and viral load could not be detected in $11(73.4 \%)$ patients after effective treatment which correspond with the study by Chopra GS et.al $(63 \%)^{3}$. Antivirals used for these patients were nucleoside analogs such as Entecavir, Lamivudine, Telbivudine. These antivirals were used for various durations (ranging from 3 months to 10 years) according to individual patient's requirement.

\section{Conclusion}

Prevalence rates of HBV vary across the world with the highest rates being observed in eastern Asia. Thus, the high sensitivity, specificity, accuracy, wide linearity, good reproducibility combined with a small sample volume equirement make this quantitative HBV rt-PCR assay in routine diagnostic laboratories well suited for application to large clinical and epidemiological studies.

\section{References}

1. Hepatitis B. World Health Organization. Department of Communicable Diseases Surveillance and Response; 2002: pp.1-76. Available at http://www.who.int/csr/disease/hepatitis/HepatitisB _whocdscsrlyo2002_2.pdfical

2. Sharma N, Ali S, Nautiyal SC, Singh V et al. Hepatitis B Virus DNA Quantification Using TaqMan Probe and its Significance. Webmed Central Molecular Biology, 2013; 4(3): WMC004042.

3. Chopra GS, Gupta PK, Anand AC, Varma PP, Nair V,Rai R. Real time-PCR HBV-DNA analysis: significance and first experience in armed forces. Military Journal of Armed Forces India. 2005; 61: 234-37. Available at: http://medind.nic.in/maa/t05/i3/ maat05i3p234.pdf

4. Rahman S, Mahtab MA, Karim MF. Guideline for treating hepatitis $B$ virus infection in Bangladesh. Viral Hepatitis Foundation Bangladesh: pp. 6-9. Available at: http://www.banglajol.info/index.php/BLJ /article/download/2619/2249.

5. Chen CJ, Yang $\mathrm{HI}$, and Uchenna $\mathrm{H}$. Hepatitis $B$ Virus DNA Levels and Outcomes in Chronic Hepatitis B. Hepatology. 2009; 49(5): (S73-S83).

6. Levinson W, Jawets E. Hepatitis viruses. In: A LANGE medical book medical microbiology \& immunology. 7th ed. USA: The MC Graw-Hill Companies; 2002: pp. 256-61.

7. Choudhury MR. Pathogenic Viruses. Modern Medical Microbiology. 5th ed. Bangladesh; 1999: pp. 516-517.

8. Geo.F. Brooks, Janets S, Karen C.Carroll, Stephen A, Morse. HepatitisViruses. A Lange medical book Jawetz, Melnick, \& Adelberg's Medical Microbiology.24th ed. USA: MC Graw-Hill Companies; 2007: pp. 466-70. 
9. Thibault V, Pichoud C, Mullen $C$ et al. Characterization of a New Sensitive PCR Assay for Quantification of Viral DNA Isolated from Patients with Hepatitis B Virus Infections. Journal of Clinical Microbiology. 2007: pp. 3948-53.

10. Locarnini S. Molecular Virology of Hepatitis B Virus, Seminars in Liver Disease. 2004; 24 (1): 3-10.

11. Tong S, Kim KH, Chante C, Wands J, Li J, Hepatitis B Virus e Antigen Variants. Int J Med Sci. 2005; 2 (1): 2-7.

12. Mahtab MA, Akber SMF, Rahman S. Hepatitis B surface antigen negative, but HBV DNA-positive patients in Bangladesh. Bangladesh Med Res Counc. Bull 2012; 38:104-9.

13. Danta M. Hepatitis B virus testing and interpreting test results. St vincent's clinical school, the university of new south wales, darlinghurst, nsw: pp. 31-9.

14. Koyuncuer A. Associations between $\mathrm{HBeAg}$ status, HBV-DNA ALT level and liver Histopathology in patients with chronic Hepatitis B. Science Journal of Clinical Medicine. Vol-3, No.6, 2014; PP 117-23.

15. Liaw YF, Kao JH, Piratvisuth T, Chan HLY, Chien RN, Liu CJ. Asian-Pacific consensus statement on the management of chronic hepatitis B: a 2012 update. Hepatol Int. 2012;6:531-61.

16. Mendy ME, Kaye $S$, et al. Application of real-time PCR to quantify hepatitis B virus DNA in chronic carriers in The Gambia. Virology Journal. 2006, 3:23.
17. Rahman MM, Rahman M, Chowdhury NG, Hossain SKB, Hossain D, Hossain R, Quadrat-E-Elahi. Long-term follow-up study of asymptomatic $\mathrm{HBsAg}$-positive carrier. Euroasian $\mathrm{J}$ Hepato-Gastroenterol. 2012;2(2):76-8.

18. Ito $\mathrm{K}$, Kim KH, Lok ASF and Tong S. Characterization of Genotype- Specific CarboxylTerminal Cleavage Sites of Hepatitis B Virus e Antigen Precursor and Identification of Furin as the Candidate Enzyme. Journal of Virology. 2009: pp. 3507-17.

19. Hepatitis B virus precore mutant. Wikipedia [Internet]. Available at: http://en.wikipedia.org/wiki/ Hepatitis_B_virus_precore_mutant.

20. Ganem D, Prince AM. Hepatitis B virus infectionnatural history and clinical consequences. The New England Journal Medicine. 2004; 350 (11): 1118-29. Available from: http://www.nejm.org/doi/full/10.1056/ NEJMra031087.

21. Ganji A, Esmaeilzadeh A and Mokhtarifar A. Correlation between $\mathrm{HBsAg}$ quantitative assay results and HBV-DNA levels in chronic HBV. Hepat Mon. 2011; 11 (5):342-5.

22. Messageot F, Salhi S, Patricia, Eon and Rossignol JM. Proteolytic Processing of the Hepatitis B Virus e Antigen Precursor. The Journal of Biological Chemistry. 2003; 278 (2): 891-5.

23. Pujol FH, Navas MC, Hainaut P, Chemin I. Worldwide genetic diversity of HBV genotypes and risk of hepatocellular carcinoma. Cancer Lett. (2009), doi:10.1016/j.canlet.2009.07.013. 